\title{
DESIGN FICTION IN DESIGN EDUCATION: A CASE STUDY ON STUDENT PROJECTS
}

\author{
Banu İnanç UYAN DUR \\ Doç., Iş̧ı Üniversitesi Sanat Tasarım ve Mimarlık Fakültesi Görsel İletişim Tasarımı Bölümü, inanc.uyan(at)gmail.com, ORCID: 0000- \\ 0003-0259-1716 \\ Uyan Dur, Banu İnanç. "Design Fiction in Design Education: A Case Study on Student Projects". idil, 82 (2021 Haziran): s. 903-914 \\ doi: 10.7816/idil-10-82-04
}

\begin{abstract}
Design fiction is a critical design approach which speculates on possible futures and forms technology-based visions on how future life might be and explains fictional worlds through the designed artefacts. Design fiction opens a free space to question current assumptions, operations, and systems. Design fiction is also used to create alternative worlds by moving away from various constraints, business expectations in particular, and to provide a convenient atmosphere for students to be able to think in a conceptual context, to develop new discourse, and to question their relation with reality. The present article argues that design fiction can be used as an instrument to question the position of design education in providing a labour force to the sector, and to move out of the structure of the design fiction that focuses on now and today. In this scope, the design fiction projects produced in the course of a Visual Communication Design Project will be examined, the methods used and the stages followed will be explained, and opinions will be presented on the possible angles of outcomes for students in design education.
\end{abstract}

Keywords: Design fiction, design education, visual communication design, speculative design

Makale Bilgisi:

Geliș: 11 Mart 2021

Düzeltme: 5 Nisan 2021

Kabul: 27 Nisan 2021

(c) 2021 idil. Bu makale Creative Commons Attribution (CC BY-NC-ND) 4.0 lisansı ile yayımlanmaktadır. 


\section{Introduction}

The paradigm change introduced by technology has made design more complex and caused an expansion in its definition and scope. The target problematic subjects of design have changed and the ways to define problems, solution methods, and work processes have become varied. Design was no longer simply a framed area and has now become a theoretical and applied study area interrelated with every field from technology to sociology. This transformation needs to be viewed as an ongoing process. In this process, the current methods in design education are questioned, and several studies have been carried out on new education models and different approaches. Methods to bring more holistic perspectives to design are becoming prominent instead of education that is entrapped from within. From the perspective of communication design education, it is already obvious that an interdisciplinary practice is required as it includes various and comprehensive study areas.

In the communication design application, one needs to pay attention to the constraints including target audience, customer, cost, production, distribution, and marketing. Together with these constraints, the aim of the designer is to achieve a unique, innovative, and impressive result by using correct communication methods. Defining the problem properly among all these variables also determines the quality of the solution. However, an important part of these problems is determined according to the requirements of industry and the solutions are produced in a manner to serve other areas as well. In this sense, design is under the influence of market and economic expectations. Communication design education is configured to provide students with on the proper tools for the sector just like a simulation of real life. The position of design education that provides a competent labor force to the sector and that attempts to provide students with employability qualities is now being questioned. Educating designers to be employable and with qualities to meet the expectations of the sector is a one-dimensional approach. On the other hand, design education should evolve towards aspiring to educate designers who can shape the world of future rather than those with simply the tools to meet the requirements of the world today. In this context, design fiction may present a suitable work atmosphere to go beyond the structure of various constraints of communication design education that focus on now and today and, more particularly, to eliminate business expectations. It would be more appropriate to deal with design fiction as a different approach rather than a new model or a design method for education.

\section{Design Fiction}

Design fiction is a study practice in the field of design which is currently in its early period. The term was first used in 2005 by Bruce Sterling, a science fiction author, in his book Shaping Things. Sterling defined design fiction in an interview in 2012 as "the deliberate use of diegetic prototypes to suspend disbelief about change" (Bosch, 2012). Lindley (2015a) states that the term diegetic means "world of the story' within the context of design fiction and a diegetic prototype refers to a prototype presented in the world of story. In the same interview, Sterling stated that design fiction is not a type of fiction, but a type of design which describes about worlds rather than tells stories (Bosch, 2012).

Defining design fiction as a concept, determining its field of study, and creating its methodology are ongoing processes. Therefore, there are different approaches to the scope of design fiction and how it should be defined. In the most general sense, design fiction is a design practice that speculates possible futures, creating technology-based visions on how life in the future could be and creating fictional future scenarios by the designed artefacts. Design fiction is a provocative and critical approach that is inspired by developing technologies, innovation, and the latest social trends and speculates the maximum points that they can reach in the future. The purpose of design fiction is related to asking questions instead of giving answers. "A design fiction is (1) something that creates a story world, (2) has something being prototyped within that story world, (3) does so in order to create a discursive space" (Lindley and Coulton, 2015). Upon reviewing the literature, we see those expressions such as story and storytelling are frequently used in the definitions of design fiction. According to Candy and Dunagan (2017), design fiction emerged from the intersection of storytelling and design. Designs resulting from design fiction are artefacts with a story. Bleecker says that the result of the designed fiction are objects with stories. "These are stories that speculate about new, different, distinctive social practices that assemble around and through these objects. Like props that help focus the imagination and speculate about possible near future worlds" (Bleecker, 2009:8). On the other hand, there are views that associate design fiction with world building. Coulton et al. (2017) posit that "design fiction is in fact a world building activity, with no inherent link to narrative or storytelling". 
Design fiction has drawn much attention in recent years, however, different perspectives presented by the studies on this subject have also increased uncertainty. Lindley (2015a) indicates that this uncertainty may cause a paradigm shift in design. These inconsistencies in definitions may exist due to the different interpretations on the content and role of the term 'fiction'. "It could imply a preoccupation with technology (Dunne \& Raby, 2013); it could suggest that the designs in question are unreal (Auger, 2013); and it could refer to the medium that the designer is using (Lindley et al., 2014)" (as cited in Lindley, 2015a). In addition, there are different approaches with respect to the ways of handling design fiction in the literature. In some publications, design fiction is handled as a design research method (Lindley, 2015b; Markussen and Knutz, 2013; Grand and Wiedmer, 2010) and in others an instrument in design projects (Candy and Dunagan, 2017; Grand and Wiedmer, 2010).

When talking about design fiction, it is necessary to mention the interrelated fields of speculative design, critical design, and discursive design. There are some common and distinct points of these fields. Their most fundamental common point is that they are all different from the market-based design perspective. Auger (2013) states that the differences are based on geographical or contextual use, but they all eliminate business constraints and use fiction to offer alternative products, systems, or worlds.

Speculative design is a field that focuses on speculation about possible futures and on alternative presents. It is related to the development of ideas, concepts, or systems instead of an approach only for the production of an object or a product. These concepts or systems may be related to technology as well as culture, sociology, or policy. "Speculative design is a discursive practice, based on critical thinking and dialogue, which questions the practice of design and its modernist definition" (Mitrović, 2015:13). Auger (2016) states that speculative design is against normative design and the lack of constraints including economy, aesthetics, technology, policy, ethics, and history allows designers to imagine different possibilities and to challenge established systems and roles. Speculative design is the closest field of study to design fiction. Again, design fiction is sometimes called "artefacts from the future" and emphasizes technological futures (Dunne and Raby, 2013).

The term Critical Design was first used in 1999 by Anthony Dunne and then developed in the book 'Design Noir' in 2001 by Dunne and Raby. According to Dunne and Raby (2007), "Critical Design uses speculative design proposals to challenge narrow assumptions, preconceptions and givens about the role products play in everyday life. It is more of an attitude than anything else, a position rather than a method". Critical design does not only challenge this business goal or the physical benefit of the object but also questions the assumptions related to the roles played by the objects in daily life. It encourages critical view against the norms that are adopted in social, cultural, and technological senses and aims to increase awareness on ethics and values systems. It offers design proposals for alternative systems, products, and services.

Discursive design is recommended as a more comprehensive, unifying umbrella term for the areas that are interrelated and intersecting at some points such as critical design, design fiction, speculative design, and adversarial design. According to the definition of Tharp and Tharp (2013:406) discursive design "refers to the creation of utilitarian objects/services/interactions whose primary purpose is to communicate ideas artefacts embedded with discourse. These are tools for thinking; they raise awareness and perhaps understanding of substantive and often debatable issues of psychological, sociological, and ideological consequence". Value fiction, future design, and radical design are also fields that can be associated with design fiction. Although these areas include differences with regards to their contextual uses, they also have some common points. They all have elements of discovery, questioning, provocation, and alternative approaches. Their common motivations include conceptual thinking, determining own problems, and developing new discourse going beyond the industrial expectations and market constraints. Design fiction focuses on future technology; however, it doesn't have the simplified goal of uplifting and praising technology alone. It also has an aspect that questions the effect of technology on society and its direction in possible futures.

\section{Design Fiction in Design Education}

Studio-based courses in communication design education proceed using design projects that may be encountered in real life in order to prepare students for the sector. The projects should take several binding elements including target audience, customer, cost, and marketing into consideration. Likewise, they will face a real-life atmosphere where industry is guided by needs, business concerns, and customer expectations. That is, needs and constraints are determined externally. "From the modernist perspective, 
design has been primarily regarded as a problem-solving practice, and usually those aimed at problems detected by other professions" (Mitrović, 2015:9). Design fiction can provide the possibility of unlimited thinking, dreaming, and discovery without externally determined needs and constraints. Students can determine their own design problems, speculate about the future, and question assumptions on design.

Design is inherently a speculative, critical, and future oriented process already. "All studio-based design education involves making speculations, which, when done on the basis of an adequate education, will have critical aspects" (Tonkinwise, 2019). Here, the important point is that design fiction focuses on the future and is a research activity carried out about future possibilities. In addition, it provides a more encouraging and provocative atmosphere for a speculative and critical process.

Design fiction is not related to things like supernatural or fantastic heroes, and it does not include a futurist fiction independent from today. It cannot be said that it is totally distant from science fiction, however, it needs to consider today when speculating about the future. When dealing with the state, use, and social results of technology in the future scenario, technological development and advance is conceptually questioned. In design fiction studies, the stories of future worlds become concrete in artefacts. Bleecker compares the design fiction objects to totems telling stories from other worlds and says that "they are like artefacts brought back from those worlds in order to be examined, studied over" (2009:7). These artefacts might be a product, service, or prototype. To give more specific examples, these artefacts can become concrete like physical prototypes, products, digital interfaces, videos, short movies, user guides, infographics, diagrams, comic books, or storyboards, etc. When placing the concept of technology in a world fiction in design fiction, the social, cultural, political, economic systems, ethical values, nature, and environmental conditions in that world are also included in the process. In this sense, students experience a multidimensional study process. As an eye looking externally at the world they fictionalized, they see how all systems from culture to economy and from policy to nature are interconnected and have a complex relation between them. Moreover, design fiction is quite convenient for working in groups including students from different areas.

Design fiction studies include various methods, applications, and instruments that are used when speculating about possible futures. These methods are used both to fictionalize future scenarios and to create artefacts. According to Grand and Wiedmer (2010) "it is important to develop a method toolbox which is characterized by a plurality of different perspectives and approaches; these methods and tools must be able to represent, visualize and document the experimentation processes; these methods and tools must allow a series of experiments, a series of questions or the series to exploration of a series of related hypotheses". Knutz, Markussen and Christensen (2014:8.3), who defined design fiction as a new approach in design research, proposed a typology of 5 criteria for design fiction: "(1) What if scenarios as the basic constructional principle of design fiction; (2) the manifestation of critique; (3) design aims; (4) materializations and forms; and (5) the aesthetic of design fictions". In the case study of the present article, a functional toolbox was created and applied gradually to students by taking these recommendations into consideration.

Methods

A design fiction project was conducted within the scope of the studio course of the Visual Communication Design Master's Program at Işı1k University in the 2020-2021 Fall Semester. Projects were completed in 10 weeks and included studio courses for 6 hours per week. 9 students participated in the course which was conducted online due to Covid-19 restrictions. This article includes 4 student projects.

\section{Method Toolbox}

For the design fiction project, a method toolbox was created consisting of the methods frequently used in future studies. The methods in the toolbox were applied in 4 stages.

First Stage - Futures Wheel:

The futures wheel, developed by Jerome C. Glenn in 1971, is a way to organize thinking of and questioning the future. "The Futures Wheel is a method for identifying and packaging primary, secondary, and tertiary consequences of trends, events, emerging issues, and future possible decisions" (Glenn, 2009). Using the futures wheel within the scope of this study, students investigated the future effects of the situation/case they put in the center to examine. A frequent situation faced in design fiction projects is that students often tend towards science fiction or fantasy. The futures wheel was included in the first stage of design fiction specifically to ensure that students were not kept on a certain ground of reality. In addition, 
the futures wheel study forced students to research the subject or case they dealt with. At this stage, students freely conducted as many futures wheels as they wanted on any subject they wanted. The addressed subjects included various topics such as artificial intelligence, blockchain, global warming, endangered insects, and migration. In this sense, the focused subjects were not limited only to developing technologies. Although students generally had difficulties in secondary effects, the futures wheel method supported them in producing ideas for the what-if scenarios, which are the most important instruments of design fiction.

\section{Second stage - What-if questions:}

What-if scenarios are used to create a hypothetical world in all design fiction studies. This method enables thinking and imagining in a wider spectrum without the constraints of the real world. The question 'what would happen if a certain situation or case took place?' is the beginning point for dreaming without constraints. The process that starts with one what-if question assists designers to produce different ideas by breaking some thinking patterns. With the futures wheel study in the first step, students put forward futures that carry a tight logical bond with the world of today. This way, they were prevented from shifting towards fantasy or science-fiction like many students did in the beginning of the study. The futures wheel exercise enabled them to study the subjects they were interested in, however, it did not provide an atmosphere of freedom as large as that provided by the what-if questions. In this sense, what-if questions are more suitable for the nature of design fiction. Design fiction is not about making a future prediction. The future is a non-linear, or a non-singular phenomenon, where unpredictable developments can take place. What-if questions open a broader space for students where they are able to discover, produce, and develop futures in a different way. At this stage, students generated 108 what-if questions with the 6-3-5 Brainwriting method. In this method, a table consisting of a cell matrix including three columns and six rows is used. Six refers to the number of participants, three refers to the number of ideas to be written by the participants in each round, and five refers to the duration of each round. Six students participating in this course generated 108 what-if questions and then each student selected a what-if question they wanted and used it as a starting point to create a fictional world.

\section{Third stage - World building:}

World building is process used to create an imaginary world. According to Alex McDowell, who defines world building as a design practice, "World building defines a philosophy and practice that exploits a rich collaboration of design and emergent technologies to create visceral narrative spaces through story logic, design process and user experience" (2015:146). World building is used in design fiction, speculative design, role-playing games, novels, cinema, and video games at different platforms. In world building, a very detailed world can be created as per the situation. Everything about that world can be fictionalized including but not limited to geographical, ecological, historical, cultural, political, economic, technological, architectural, belief systems, and linguistics. All these elements have to be integrated to each other in a persuasive, consistent, and compatible manner. Questions in the created world like what are the social order, political atmosphere, economic situation, climate and nature conditions?', 'what are the phenomena, events and trends of that world?', 'who are the products, services, or models designed for?' provide a contextual atmosphere for artefacts. The people, systems, and objects existing in the created world cannot be considered separately from each other.

In the third stage, students also developed applied design ideas. There are two reasons for the decision to carry out world building and applied design ideas in parallel within this course plan. The first reason was to enable students to establish a tight bond with the artefacts they would design and the world in which the artefacts would exist. The second reason was to prevent the risk that the students might spend more time and energy on one of them while ignoring the other (world building or applied design). Students accumulated and organized their ideas, research, articles, and sketches (articles, news, visual, graphics, etc.) using an online whiteboard platform. Every student deepened his or her research in the fields including technology trends, cultural values, ethnography, ecology, and food depending on the subject matter. This stage was the busiest process as it also included critical discourse. Although each student had another project, an attempt was made to create an atmosphere of group study by making joint discussion and idea development compulsory within the course. The ideas about the application design were clarified at this stage. Answers were provided to the most fundamental questions like where, why and by whom would this design be used? In addition, some students conducted their designs according to a certain user 
by creating a living character in their fictional world.

\section{Fourth stage - Design project:}

At this stage, students decided the most convenient method to materialize their design ideas and they concluded their works. As the main objective of the design fiction work within the scope of this course was to remove themselves from established thinking patterns and to obtain new perspectives, more importance was assigned to the production of ideas. Therefore, students were left free to materialize their ideas by any method they found themselves to be competent in. All of them preferred digital production of their ideas (illustration, infographic, animation, user interface design) and none wanted to produce an object physically (model, prototype). Some students also made storyboards in order to show how the products or services they designed were used within the own reality of their fiction worlds.

\section{Design Fiction Projects}

Plantouch:

This project is based on a pessimistic fiction of the future using the frequently applied scenario of nuclear disaster. Due to nuclear wars, radioactive fall-out caused contamination of soil and waters and the ecosystem collapsed. This disaster brought all creatures on earth to the point of extinction. Central authorities were dissolved, and the few remaining survivors tried to remain alive in groups. After long years, the earth began regenerating and new plant species emerged. Some of these plants were completely novel while others were the genetically modified versions of the old species. Both groups include toxic plants. Within the scope of world building, a phytologist character named Pole was created. Pole learned phytology through the master-apprentice relationship. In this world, phytologists use wearable technology connected to a central network to re-classify all plants. This wearable technology is called Plantouch and consists of gloves and a display that can be fixed to and removed from the arm. The technology is important for these remaining survivors because plant classification is necessary for nutrition and drug production. (Figure 1).

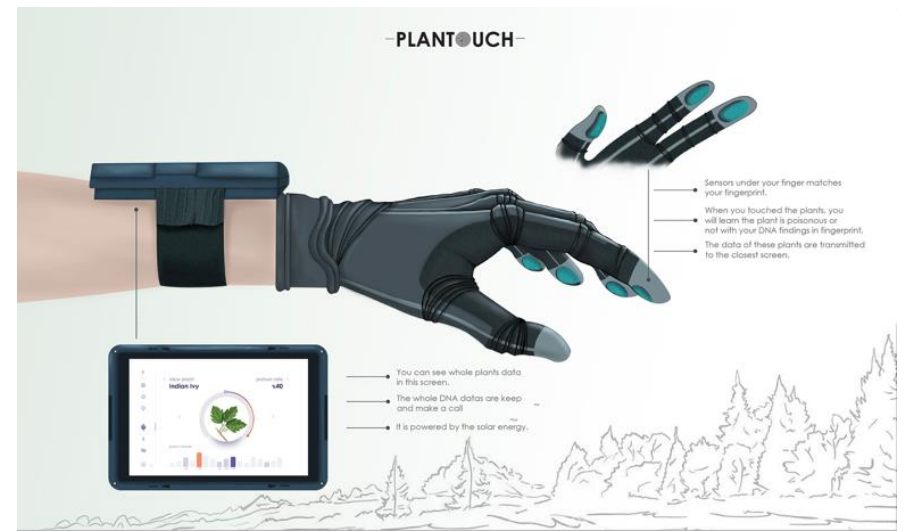

Figure 1. Planttouch, student project, Sümeyye Yoldaş, 2021.

The smart glove is able to identify plants thanks to the technology embedded on its fingertips and the information provided can be seen on the display. This technology detects the DNA compatibility of the DNA from the plant that is touched with that of human DNA and displays all structural content particularly including the plant's radiation levels and whether it is toxic or not. In this way, the phytologist is able to match the found plants with those defined in the network and enter information in the system if the plant species is novel. This project visualized the wearable plant definition technology with an illustration and through the use of a storyboard (Figure 2). 


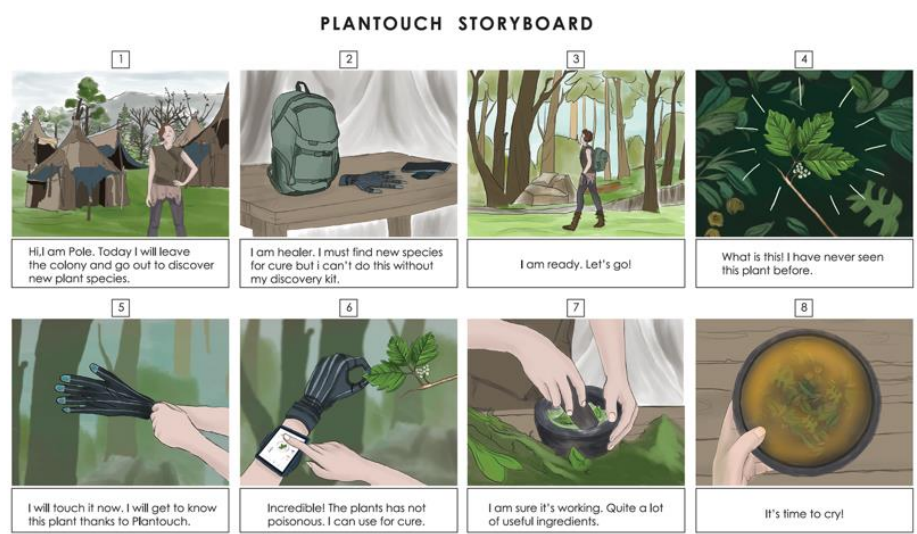

Figure 2. Storyboard for Planttouch, student project, Sümeyye Yoldaş, 2021.

The project describes a pessimistic future that the world can be dragged into through superiority wars and destruction of nature, and criticizes human ambition, greed, and recklessness. The wearable plant identification technology seems to bring a solution to a vital problem in such a world; however, it actually indicates the dark possibility that humankind may be surrounded by toxic plants in the future.

$\mathrm{MicrO}^{2}$ :

This project was shaped on the theme of underwater living spaces established in the future. The balance of nature was destroyed due to climate change and environmental disasters which caused glaciers to melt and lands to become submerged. As the ozone layer protecting the earth from harmful solar rays gradually depleted, it became impossible to live on the land. While these processes were ongoing, humanity built underground living spaces after realizing that their environmental issues had reached an irrever sible point. According to the project's world building, humanity had been underwater for 50 years and an underwater archaeologist character living in this world was created. Within the scope of the project, smart underwater apparel was designed and the idea of micro needles that provide oxygen to be used in emergencies was developed (Figure 3).

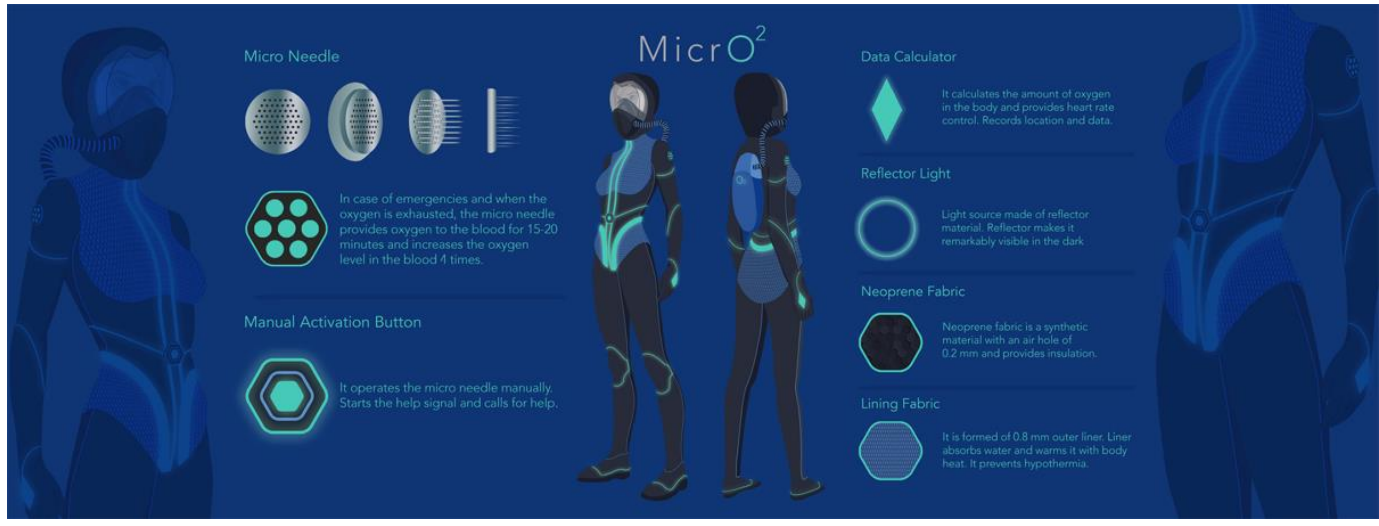

Figure 3. MicrO², student project, Elif Tă̆, 2021.

When the oxygen tube fails or runs out, these micro needles inject oxygen-filled microparticles into the blood which can keep people alive for 15 to 20 minutes. This emergency device is used by depressing a trigger button which automatically injects the microparticles in the event an oxygen problem is experienced. At the same time, a distress call is sent out when the trigger is pushed. This project was developed due to influence from the research on injectable oxygen gas-filled microparticles conducted by Dr. John N. Kheir and his team (2012). The project criticizes humankind for recklessly damaging nature despite the warnings of scientists. Underwater apparel and micro oxygen particles seem to bring solution to an important problem in the world; however, the real issue is the fact that humankind has been forced into an environment that is detached from the land and to which it does not belong.

Armoire mirror: 
Contrary to the other student works produced within the scope of this course, this project does not include a pessimist world. Yet, in the history of the fictional world that was created, increases in global carbon emissions and carbon dioxide emissions caused global warming, the number of substantial environmental catastrophes increased, and the ecological balance collapsed. However, this negative course of events was stopped thanks to globally taken radical decisions. Decisions, that are similar to but much stricter than the Kyoto Protocol, were taken to reduce the greenhouse gas emission values. The world gradually entered into a more sustainable system. As a result of the long-lasting transformation, nature turned back to its former condition and the ecosystem recovered. In this transformation process, humankind's perspective on life, their value systems, and consumption habits changed. Technology also advanced at this time. Contrary to the future scenarios created by the other students, this technology brought humanity to a better point.

The project deals with consumption habits from the aspects of the fashion industry. People have a single outfit in this new world order which can be termed a wearable technology covering the whole body. A desired digital clothing product can be selected from the online shop and the wearable technology reflects these digital clothes. Every person has a lens in the eye, which is a much more developed version of AR technology, so that these digital clothes can be seen. The AR lens is an important technology that is effectively used in the fictional world. It is a technology that is widely used in many areas from urban information system to health data, not only in the digital cladding for apparel, furniture, and decoration. The student carried out an interface design for an interactive mirror within the scope of the project (Figure 4). Users are able to select digital clothes from the interactive mirror and try them on. The interactive mirror can be used to access to the clothes shopping platform or the person's personal digital wardrobe.
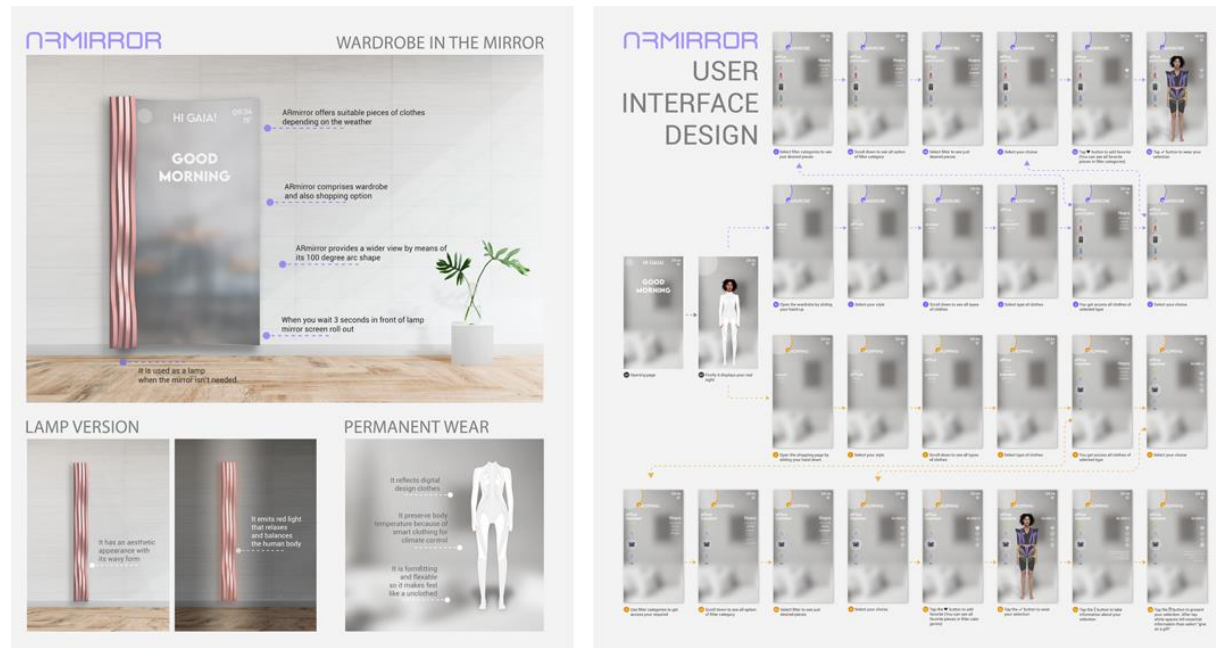

Figure 4. Armoire mirror, student project, Ayşe Merve Köse, 2021.

The project criticizes the consumption world of today where economic interests play a role. This consumption-based system cannot offer what is promised and causes irreversible damages to nature. People purchase many unnecessary products just to own them and consequently all these products are returned to nature as waste. The appeal created by the concept of fashion makes the purchased products unfavorable after a while. Within this project, fashion continues with the use of digital clothes and the economic cycle is provided through digital clothes shops. Digitalization of clothing may trigger more consumption by causing an increase of options. Yet, nature is prioritized within the logical reality of the fictional world and the technology does not pollute the environment. In this sense, the production of digital clothes does not utilize resources and pollute the environment unlike the textile industry of the present world.

Dream it:

In this project, a pessimistic world fiction was created in which giant companies rule the world. These giant corporations demand high work performance from their employees. Extreme workloads with high standards have driven people into depression. People cannot spare time for themselves, for relaxation and socialization, and gradually become lonelier. People resort to artificial escape routes to deal with this relentless system. An artificial dream implant is one of these ways. This device is called Dream It and 
includes various dream themes based on peace and happiness. People can select dreams before going to sleep and have dreaming experiences giving them peace and happiness thanks to this brain implant.

This project was inspired by the research of Dr. Yukiyasu Kamitani and his team on a nervous decoding method that can decipher/estimate visual images in brain during sleep and by Neuralink, an implantable brain-machine interface project by Elon Musk. The findings of the scientists "demonstrate that specific visual experience during sleep is represented by brain activity patterns shared by stimulus perception, providing a means to uncover subjective contents of dreaming using objective neural measurement" (Horikawa et al., 2013). The student imagined the technical dimension of the project by assuming that the nervous decoding method can be operated reversely. According to the project, dreams are converted to nervous codes through algorithms and then transferred to the implant. Defined nervous codes enable visualization of the selected dream in the brain. The student designed a guide for this work including pictograms showing the operation principle and possible side effects of the Dream It device (Figure 5).

The Dream It project offers people an artificial escape route within the own reality of the fictional world. However, it cannot offer a solution for the main problem: the system that uses up humans. The project was based on the idea that giant companies that shape the direction of the world with their huge budgets today would capture the decision and administration mechanisms of the future. In addition, the project criticizes the pressure put on people due to working hours and high-performance expectations in the actual world at present.

1. How It Works?

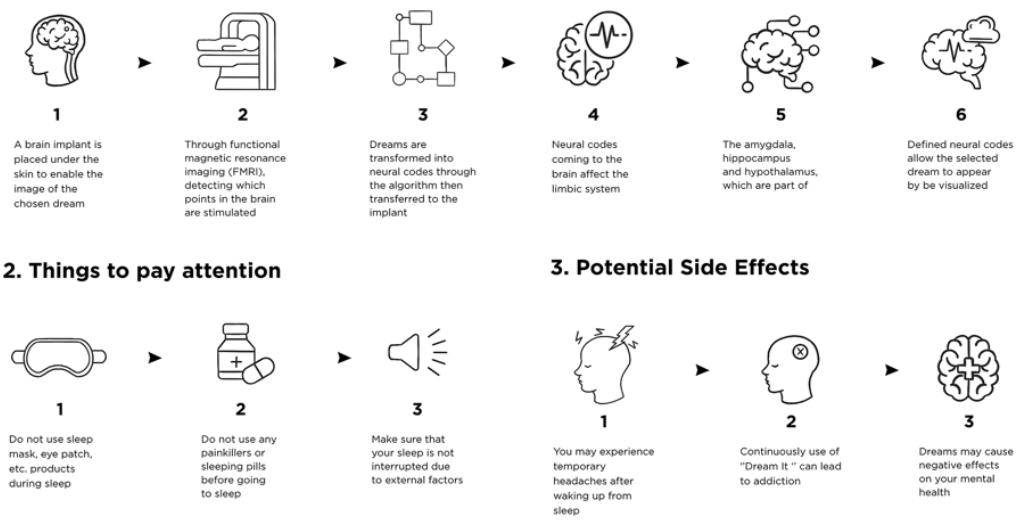

Figure 5. Dream it, student project, Derin Ekin Kenter, 2021.

\section{Discussion}

Design fiction was used as an instrument for the students to question, discuss, try, and test all existing paradigms and conventions (design, society, economy, policy, etc.). The study took 10 weeks and every stage of it provided students with a new experience they had not faced before. The fact that the design fiction works did not include a pre-defined problem drove students to research further design processes than those they were used to. The 'what-if' method was an effective instrument for the students to start thinking about the problems based on certain assumptions. They experienced within the world building process the difficulty of creating a world that is consistent in its own reality. Although they built fictional worlds, they saw that there had to be a logical and cohesive bond between the elements including design, policy, technology, economy, and social order. This increased their efforts to understand the patterns in the real world. Additionally, they experienced within the world building process the fact that the social, cultural, political, or economic systems that seem positive idea might in fact have unexpected or undesired effects. In this sense, it was determined that fiction could be used as an instrument to think of the possible outcomes of certain situations, conditions, or systems.

In the design fiction works, the stories of the future worlds are embodied in the designed artefacts. The designed artefact and the surrounding world need to be considered as a whole. In this sense, it was seen that it would be a good method to achieve more consistent results if students developed their product and service design ideas simultaneously with world building in this course. Other than the 'Armoire Mirror' project, all projects took place in a dark future fiction. In this sense, the negative psychological effects of 
the Covid-19 pandemic might have affected the future speculations of the students. In negative fictions, speculations were made mainly on possible futures in which substantial environmental disasters might drag the world down into darkness. In reviewing the practical works, all of the product and service designs were found to be for individual use. In the 'Plantouch' and 'MicrO2' projects, the designed products were for survival. In this sense, students imagined the future as a world based on self-protection where personal equipment is necessary to survive. The 'Dream It' project is an exaggerated and dramatized version of today's business life. In this project, people are dependent on another product to protect themselves mentally and spiritually rather than physically.

Design fiction provides flexibility in some principles which are included in the current definition of design. Still, upon reviewing the product and services designs in the projects, it was observed that usercentered design approach was maintained. Designs are functional works that facilitate and improve people's lives within the reality of the created fictional world. In addition, it can be said that the works are compatible with the trends in current design principles with respect to visualization. Yet, they do not devalue or disconfirm the works. What is important is that they formulated their questions, thought freely out of the commercial mechanisms, questioned current assumptions, discussed their projects, and determined their own ways instead of finding solutions to externally introduced problems when they conducted future speculations throughout the 10 week process. "The work created by students at college is to push their understanding of a discipline, not produce design as it exists in the cut and thrust of industry (fictional or not). This doesn't mean that the quality of the work is weaker, it's just do ing a different thing" (Ward, 2013). In this sense, the produced projects should be considered to be a part of the learning process.

\section{Conclusions}

Design is inherently a critical, speculative, and future oriented process. From this perspective, it is clear that a properly founded design education would bring multidimensional qualities to students without requiring methods and approaches. Transformations in social, economic, and political fields, and particularly technological developments, take place in an unprecedented speed. The concepts of change and transformation now refer to continuity rather than processes with a beginning and an end. The fact that everything becomes more complex brought the need for a paradigm change in design education, like in every field. In the last 20 years, new terms, methods, and approaches have been introduced in the field of design with some becoming more popular at some periods and disappearing later on. This refers to the research created by the change in paradigm. The need for a transformation in design education is one of the rare subjects agreed upon by everyone. New methods and approaches are being developed and tested for this purpose. It would be more appropriate to address design fiction as a different approach rather than a new model or a design method for education. Design fiction may present a convenient working atmosphere in order to get out of the structure of design education that focuses on now and today and to eliminate several constraints, particularly business expectations. It opens a critical field of dialogue to consider design fiction within a conceptual context, to develop new discourse, and to question relations with reality. It can be used as an instrument for questioning current assumptions, functioning and systems covering all aspects including social, cultural, and political and particularly including design. If implemented properly within suitable time periods, design education can be an effective approach for students to develop new discourse, to dream about, discover, and question the future. Students may gain awareness on the political, economic, and cultural factors that determine the role of the design practice. Design fiction presents a unique atmosphere of discussion to find new ideas, to think of different possibilities, and application methods.

A toolbox of four stages was created for the design fiction work that was created within the scope of this paper. Students advanced to their practical work after the stages of futures wheel, what-if questions, and world building were completed, respectively. In the world building stage, students created fictional worlds that function logically within their own realities. World building was found to be a very useful method to move students away from their pre-established design perceptions and expertise descriptions. Speculating about the future enabled them to think of different possibilities and become curious about how else the real world could be apart from its current functioning. Removing business mechanisms from the equation presented students a freer atmosphere of thinking and triggered their creativity. In addition, the fact that no defined problem or brief was provided in the course drove students to search for different processes than 
those they were used to. The fact that students came across unpredictable contradictions in their design fiction works is an important experience for the development of their capacity to cope with the unknown. In this context, it can be said that the design fiction works may bring the flexibility to adapt to the complicated and changing world which is always in a transformation. This study had one main limitation. Some changes had to be made in the content planning of the course in the 2020-2021 Fall Semester due to the Covid-19 pandemic. Group projects with students from different disciplines could not be realized it was not possible to provide convenient conditions. Carrying out design fiction studies within a system based on cooperation including participants from different disciplines would bring much better results.

\section{References}

Auger, James. "Speculative Design: Crafting the Speculation”. Digital Creativity 24.1 (2013): 11-35.

—. "James Auger interview". In I. Mitrović, \& O. Suran (Eds.), Speculative - Post-design practice or new ütopia? 2016: 15-16. Zagreb: Ministry of Culture of the Republic of Croatia \& Croatian Designers Association, 2016.

Bleecker, Julian. Design Fiction: A Short Essay on Design, Science, Fact and Fiction. Near Future Laboratory, 2009.

Candy, Stuart and Dunagan, Jake. "Designing an Experiential Scenario: The People Who Vanished". Futures 86 (2017):136153.

Coulton, Paul and et al. "Design Fiction as World Building". Proceedings of RTD Conference (2017): 163-179.

Dunne, Anthony and Raby, Fiona. Critical Design FAQ (online), 2007. http://dunneandraby.co.uk/content/bydandr/13/0 (accessed 01 Nov 2020).

- Speculative Everything. London: The MIT Press, 2013.

Glenn, Jerome C. The Futures Wheel (online), 2009. http://www.millennium-project.org/wp-content/ uploads/2020/02/06Futures-Wheel.pdf (accessed 19 Dec 2020).

Grand, Simon and Wiedmer, Martin. "Design Fiction: A Method Toolbox for Design Research in A Complex World". Proceedings of the DRS 2010 Conference: Design and Complexity (2010): 562-577.

Horikawa, Tomoyasu and et al. "Neural Decoding of Visual Imagery During Sleep”. Science, 340. 6132 (2013): 639-642.

Kheir, John N. and et al. (2012) "Oxygen Gas-Filled Microparticles Provide Intravenous Oxygen Delivery". Science Translational Medicine 4.140 (2012): 140ra88.

Knutz, Eva., Markussen, Thomas. and Christensen, Poul Rind. "The Role of Fiction in Experiments within Design Art \& Architecture - Towards a New Typology of Design Fiction”. Artifact 3.2 (2014): 8.1-8.13.

Lindley, Joseph. “A Pragmatics Framework for Design Fiction”. Proceedings of 11th EAD Conference: The Value of Design Research (2015a): 1-10.

—. "Researching Design Fiction with Design Fiction". Proceedings of the 2015 ACM SIGCHI Conference on Creativity and Cognition (2015b): 325-326.

Lindley, Joseph., Sharma, Dhruv and Potts, Robert Joseph. “Anticipatory Ethnography: Design Fiction as an Input to Design Ethnography" Proceedings Ethnographic Praxis in Industry Conference (2014): 237-253.

Markussen, Thomas and Knutz, Eva. "The Poetics of Design Fiction". In M. Blyth (Eds.), Proceedings of the 6th DPPI (2013): 231-240.

McDowell, Alex. "The Evolution of World Building as a New Design Practice". In M. Ibanez \& D. J. Gerber (Eds) Paradigms in Computing: Making, Machines and Models for Design Agency in Architecture (2015): 143-149.

Mitrović, Ivica. "Introduction to Speculative Design Practice". In I. Mitrović \& M. Golub (Eds) Introduction to Speculative Design Practice: Eutropia, A Case Study. Zagreb: HDD \& DVK UMAS (2015): 8-23.

Sterling, Bruce. "Sci-fi writer Bruce Sterling explains the intriguing new concept of design fiction, interview by Torie Bosch". Slate (2012). https://slate.com/technology/2012/03/ bruce-sterling-on-design-fictions.html (accessed 01 Nov 2020)

Tharp, Bruce M. and Tharp, Stephanie M. "Discursive Design Basics: Mode and Audience”. Nordic Design Research Conference (2013).

Tonkinwise, Cameron. "Inteview with Cameron Tonkinwise". Speculativeedu (2019) https://speculativeedu.eu/ interviewcameron-tonkinwise/ (accessed 09 Jan 2021).

Ward, Matt. "Design Fiction as Pedagogic Practice”. Medium (2013). https://medium.com/@matthewward/design-fiction-aspedagogic-practice-9b1fbba7ae2b (accessed 30 Jan 2021). 


\title{
แỉili
}

\section{TASARIM EĞITTIMINDE TASARIM KURGUSU: ÖĞRENCI PROJELERI ÜZERINE BİR VAKA ÇALIŞMASI}

\author{
Banu İnanç UYAN DUR
}

$\ddot{O Z Z}$

\begin{abstract}
Tasarım kurgusu, olası gelecekler üzerine spekülasyon yapan, gelecekteki yaşamın nasıl olabileceğine dair teknoloji odaklı vizyonlar oluşturan ve tasarlanan artifaktlar ile kurgusal dünyaları anlatan eleştirel bir tasarım yaklaşımıdır. Tasarım kurgusu, mevcut varsayımları, işleyişleri ve sistemleri sorgulamak için özgür bir alan açar. Ticari beklentiler başta olmak üzere pek çok kısıttan uzaklaşarak olası gelecekler üzerine spekülasyon yapmak ve alternatif dünyalar yaratmak için kullanılan tasarım kurgusu, öğrencilerin kavramsal bağlamda düşünebilmeleri, yeni söylemler geliştirebilmeleri ve gerçeklikle olan ilişkilerini sorgulayabilmeleri için uygun bir ortam sağlar. Bu makalede, tasarım eğitiminin sektöre iş gücü sağlayan konumunu sorgulamak, tasarım eğitiminin şimdiye ve bugüne odaklanan yapısının dışına çıkmak için tasarım kurgusunun bir araç olarak kullanılabileceği öne sürülmektedir. Bu kapsamda Görsel İletişim Tasarımı Proje dersinde üretilen tasarım kurgusu projeleri incelenecek, kullanılan yöntemler, izlenen aşamalar açıklanacak ve tasarım eğitiminde öğrencilere hangi açılardan kazanımlar sağlayabileceği üzerine görüşler sunulacaktır.
\end{abstract}

Anahtar Kelimeler: Tasarım kurgusu, tasarım eğitimi, görsel iletişim tasarımı, spekülatif tasarım 